\title{
Analisis Moderasi Religiusitas Pada Pengaruh Pendidikan, Pengalaman dan Motivasi Terhadap Kinerja Pegawai Pemprov Sumut
}

\author{
Muslim Marpaung ${ }^{1)}$, M Ridwan $^{2)}$ Sulastri Sriani ${ }^{3)}$, Purnama Ramadani Silalahi ${ }^{\left.4^{*}\right)}$ \\ ${ }^{1}$ Fakultas Keuangan dan Perbankan Syariah, Politeknik Negeri Medan \\ ${ }^{2,3,4}$ Fakultas Ekonomi dan Bisnis Islam, Universitas Islam Negeri Sumatera Utara \\ *Email korespondensi: purnamaramadani@uinsu.ac.id
}

Abstract

The low budget absorption capacity of Regional Apparatus Organizations (OPD) and cases of corruption involving government employees reflects the low awareness of employee religiosity and has an impact on the lack of performance of government employees. This study aims to analyze and evaluate the performance of employees within the Provincial Government of North Sumatra in terms of education, experience, motivation with religiosity as a moderating variable. This study uses a quantitative approach. Data analysis used the Moderated Regression Analysis (MRA) test. The results obtained that partially, experience and motivation have a significant effect on the performance of the North Sumatra Provincial Government employees. But partially, education has no significant effect on the performance of the North Sumatra provincial government employees. Simultaneously, education, experience and motivation have a significant effect on the performance of the North Sumatra Provincial Government employees. Meanwhile, Religiosity strengthens the influence of Education, Experience, and Motivation on Employee Performance.

Keywords : Education, Experience, Motivation, Religiosity, Performance.

Saran sitasi: Marpaung, M., Ridwan, M., Sriani, S., \& Silalahi, P. R. (2021). Analisis Moderasi Religiusitas Pada Pengaruh Pendidikan, Pengalaman dan Motivasi Terhadap Kinerja Pegawai Pemprov Sumut. Jurnal Ilmiah Ekonomi Islam, 7(02), 669-678. doi: http://dx.doi.org/10.29040/jiei.v7i2.2152

DOI: http://dx.doi.org/10.29040/jiei.v7i2.2152

\section{PENDAHULUAN}

Pegawai merupakan salah satu faktor yang harus diperhatikan dalam suatu perusahaan dan organisasi pemerintahan karena mereka adalah kunci utama kesuksesan perusahaan dimasa sekarang maupun di masa mendatang dan merupakan asset sebuah perusahaan untuk membuat perusahaan terus maju dan bertahan dalam perkembangan perusahaan. Pegawai yang memiliki kinerja yang baik akan dapat menjalankan pekerjaan sesuai dengan tugas yang dibebankan padanya, mengerti kaitan pekerjaanya dengan tugas orang lain, mengerti target perusahaan, serta mampu mengatasi kesulitan yang dihadapi dalam menjalankan tugasnya (Wungow Raymond Octavianus, 2018). Ada beberapa faktor yang harus diperhatikan agar kinerja pegawai dapat terlaksana dengan optimal. Menurut Sutermeister, kinerja dipengaruhi oleh "motivasi, kemampuan, pengetahuan, keahlian, pendidikan, pengalaman, pelatihan, minat, sikap kepribadian kondisi-kondisi fisik dan kebutuhan fisikologis, agama, kebutuhan sosial dan kebutuhan egoistic (I Kadek Yogi Setiawan, 2015). Menurut I Kadek, Latar belakang pendidikan dan pengalaman kerja pegawai menentukan kualitas dan kuantitas kinerja pegawai (I Kadek Yogi Setiawan, 2015). Menurut Glock dan Stark bahwa agama adalah sistem simbol, sistem keyakinan, sistem nilai, dan sistem perilaku yang terlembagakan dan semua itu berpusat pada persoalan-persoalan yang dihayati sebagai yang paling maknawi (ultimate meaning) (Ade Ratna Ningsih, dkk,2018)

Dalam konteks agama Islam, Aktivitas beragama bukan hanya terjadi ketika seseorang melakukan perilaku ritual (beribadah), tapi juga ketika melakukan aktivitas lain yang didorong oleh kekuatan supranatural. Bukan hanya yang berkaitan dengan aktivitas yang tampak dan dapat dilihat dimata, tapi juga aktivitas yang tidak tampak dan terjadi dalam hati seseorang. Sikap religius dalam dalam diri manusia dapat tercermin dari cara berpikir dan bertindak (Ade 


\section{Jurnal Ilmiah Ekonomi Islam, 7(02), 2021, 670}

Ratna Ningsih, dkk,2018). Dalam Teori Atribusi, perilaku seseorang merupakan kombinasi dari

kekuatan internal (dari dalam diri) yakni kepribadian, persepsi diri, kemampuan, keyakinan/religi dan motivasi. Dipadukan dengan kekuatan eksternal (dari luar diri) yaitu kondisi sosial, lingkungan, pendidikan, pengalaman dan pandangan masyarakat (Wayan Suartana, 2010)Teori penetapan tujuan mengisyaratkan bahwa seorang individu berkomitmen pada tujuan yang hendak dicapai (Stephen P. Robbins and Timothy A. Judge, 2014). Berdasarkan penelitian Zahratul Mufidah, latar belakang pendidikan, beban kerja, lingkungan non fisik berpengaruh terhadap kinerja pegawai (Zahrohtul Mufidah, 2017). Namun pada penelitian I Kadek Yogi Setiawan justru menemukan hasil yang berbeda dimana latar belakang pendidikan tidak berpengaruh terhadap kinerja namun pengalaman berpengaruh terhadap kinerja (I Kadek Yogi Setiawan, 2015). Penelitian Muhammad Teguh dkk menemukan bahwa latar belakang pendidikan, pengalaman dan pelatihan tidak memiliki pengaruh terhadap kinerja. Rattu Andrey dkk, menemukan pengalaman kerja dan motivasi berpengaruh secara simultan dan parsial terhadap kinerja (Rattu Andrey,2019). Sementara itu, Rina Setiawati menemukan bahwa

Religiusitas,profesionalisme, dan Human Capital mempunyai pengaruh positif dan signifikan terhadap Kinerja pada Pegawai BMT Al Amin Gombong.

Dalam upaya meningkatkan kinerja Pegawai Pemprov Sumut, Gubernur Sumatera Utara Edy Rahmayadi senantiasa mengajak pegawai Pemprov Sumut Utara untuk meningkatkan kinerjanya dan bekerja dengan hati dalam melayani masyarakat.31 Berbagai upaya telah dilakukan Pemprov Sumut saat ini untuk meningkatkan kinerja pegawainya seperti memberikan penghargaan pada pegawai-pegawainya, memberikan apreasi pada pegawai yang displin maupun memberikan hukuman pada pegawainya baik berupa teguran tertulis, lisan dan sampai penurunan gaji dan pangkat. Hal ini dilakukan dalam rangka mendukung pencegahan tindakan korupsi, pencucian uang maupun penyalahgunaan wewenang atas jabatan yang diemban pegawai pemerintahan dan pelanggaran lainnya, dibutuhkan bekal moril dan ketaqwaan kepada Tuhan Yang Maha Esa dari dalam diri untuk membentengi diri dari tindakan-tindakan korupsi maupun penyalahgunaan wewenang.
Permasalahan saat ini yang terjadi ialah Gubenur Sumatera Utara (Bapak Edy Rahmayadi) mengaku belum puas melihat kinerja pegawai dilingkungan pemerintah Provinsi Sumatera Utara. Hal ini sejalan dengan masih minimnya daya serap anggaran perOrganisasi Perangkat Desa OPD (Carolin Damanik, 2018). Kesesuaian pendidikan dari pegawai Pemprov Sumut harusnya dapat mendorong kinerja pegawai pemerintahan. Sebagai faktor input internal, indicator utama dalam tenaga kerja merupakan tingkat kemampuan dalam pendidikan karena tingkat pendidikan memberikan pengaruh secara nyata terhadap tingkat kemampuan atau kinerja. Lebih jauh Ali menyatakan bahwa pendidikan menyiapkan sumber daya manusia dengan kompetensi-kompetensi yang diperlukan bagi kehidupan, seperti kompetensi keagamaan, akademik, ekonomi maupun sosial.kompetensi ini diperukan dalam upaya peningkatan kemampuan ditengah perkembangan sains dan teknologi yang sesuai dengan jenjangnya (Mohamad Ali, 2009). Demikian dengan pengalaman kerja pegawai Pemprov Sumut yang tentunya sudah menguasai bidang pekerjaannya bertahun-tahun tentunya dituntut mampu

menghadapi setiap tantangan dan problematika di lingkungan Pemprov Sumut. Serta adanya penguatan positif maupun negative yang ditunjukkan dari adanya hukuman dan penghargaan pegawai pemerintahan dalam bekerja tentunya akan menjadi motivasi bagi pegawai untuk lebih baik dan sebagai wujud penerapan nilai-nilai Islam di dalam bekerja untuk mendekatkan diri kepada Allah SWT. Pengukuran kinerja pegawai menjadi hal yang sangat penting dalam sebuah kajian penelitian (Yustin Poiyo,2018). Penelitian ini bertujuan untuk menganalisis dan mengevaluasi kinerja pegawai di lingkungan Pemerintah Provinsi Sumatera Utara ditinjau dari sisi pendidikan, pengalaman, motivasi dengan religiusitas sebagai variabel moderasi. Berdasarkan uraian tersebut, skema kerangka pemikiran sebagai berikut :

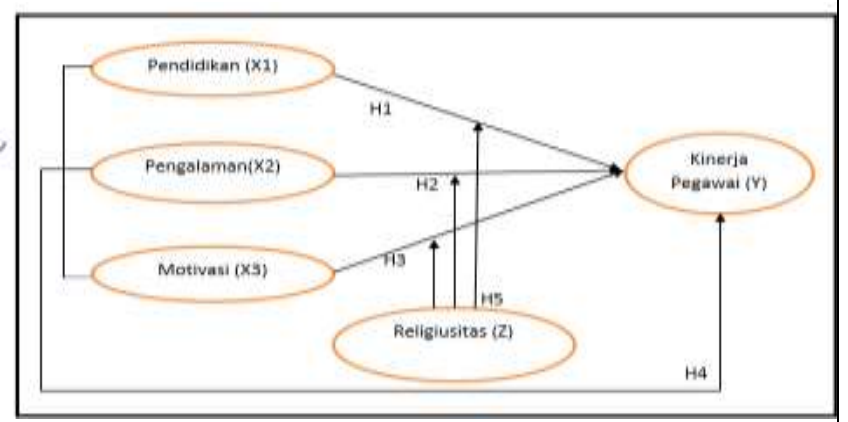

Gambar 1 Kerangka Pemikiran 


\section{Jurnal Ilmiah Ekonomi Islam, 7(02), 2021, 671}

Hipotesis yang diajukan dalam penelitian ini adalah pendidikan, pengalaman dan motivasi secara bersama-sama (simultan) maupun secara terpisah (parsial) berpengaruh terhadap kinerja pegawai pemprov sumut. Pengaruh pendidikan, pengalaman dan motivasi terhadap kinerja pegawai Pemprov Sumut dengan religiusitas sebagai variabel moderating.

\section{METODE PENELITIAN}

Penelitian ini menggunakan pendekatan kuantitatif. Metode yang digunakan ialah metode survey. Sumber data yang digunakan ialah data primer dengan memberikan kuesioner kepada responden. Diperkuat dengan data sekunder yang bersumber dari jurnal, website, buku-buku dan informasi yang relevan. Populasi dalam penelitian ini adalah pejabat atau pimpinan level atau eselon III dan IV di Pemerintahan Provinsi Sumut yang berjumlah 466 orang yang sedang menduduki jabatan yang tersebar di beberapa Badan dan Dinas Pemerintah Provinsi Sumut. Sementara itu, sampel penelitian ditentukan dengan rumus Slovin, sehingga sampel dari penelitian ini sebesar 82,3 yang dibulatkan menjadi 83. Teknik yang dipakai adalah teknik accidental sampling dimana peneliti memberikan kuesioner penelitian kepada responden yang ditemui di lokasi penelitian yang menduduki eselon III dan IV di lingkungan Pemerintah Provinsi Sumut. Teknik Pengumpulan data menggunakan Kuesiner dengan skala likert 1-5. Teknik analisis data menggunakan uji Moderated Regression Analysis (MRA), Uji Koefisien determinasi, Uji statistik $\mathrm{T}$ dan Uji statistik $\mathrm{F}$. Pengujian dilakukan dengan alat uji SPSS versi 25.

Adapun definisi operasional variabel dalam penelitian ini sebagai berikut:

a. Pendidikan

Pendidikan dalam penelitian ini adalah pendidikan terakhir pegawai di lingkungan pemerintah Provinsi Sumut pada Tingkat Eselon III dan Eselon IV berdasarkan ijazah formal dan non formal. Dimensi tingkat pendidikan yang digunakan dalam penelitian ini adalah: (1) pendidikan formal dengan indikatornya: a) jenjang pendidikan terakhir yang ditamatkan oleh pekerja, dan b) kesesuaian jurusan; (2) dimensi pendidikan nonformal dengan indikatornya relevansi pendidikan nonformal yang pernah diikuti dengan pekerjaan sekarang; dan (3) dimensi pendidikan informal dengan indikatornya sikap dan kepribadian yang dibentuk dari keluarga dan lingkungan (Desak Ketut Ratna Dewi, 2016).

b. Pengalaman

Pengalaman dalam penelitian ini adalah tingkat pengetahuan serta keterampilan pegawai di lingkungan pemerintah Provinsi Sumut pada Tingkat Eselon III dan Eselon IV. Foster indikator pengalaman kerja adalah: (1) Lama waktu atau masa kerja, (2) Tingkat pengetahuan dan keterampilan yang dimiliki, (3) Penguasaan terhadap pekerjaan dan peralatan, (4) Jenis pekerjaan (Bill Foster)

c. Motivasi

Motivasi dalam penelitian ini yaitu kepuasan kerja seseorang diukur dengan menghitung selisih apa yang seharusnya diinginkan dengan kenyataan yang dirasakan. Dimensi motivasi kerja yang digunakan dalam penelitian ini yaitu merujuk pada penelitian Desak Ketut Ratna Dewi, dkk yaitu: 1). Gaji dengan indikatornya:(a) kesesuaian gaji yang diterima dengan harapan karyawan (b) kemampuan gaji dalam mencukupi kebutuhan, dan (c) kesesuaian gaji dengan beban kerja yang diterima karyawan; 2). rekan kerja dengan indikatornya keakraban hubungan dengan atasan dan teman kerja; 3). kondisi kerja dengan indikatornya: (a) kenyamanan kondisi fisik dan nonfisik di tempat kerja (Desak Ketut Ratna Dewi, 2016).

d. Religiusitas

Religiusitas yang dimaksud dalam penelitian ini ialah tindakan menghadirkan Tuhan Yang Maha Esa dalam setiap aktifikas pekerjaan yang dilakukan oleh pegawai di lingkungan pemerintah Provinsi Sumut pada Tingkat Eselon III dan Eselon IV. Adapun dimensi pengukuran dari religiusitas adalah: (1) Religiusitas sebagai dimensi keyakinan, (2) Religiusitas sebagai dimensi praktik, (3) Religiusitas sebagai dimensi pengamalan, (4) Religiusitas sebagai dimensi pengetahuan, (5) Religiusitas sebagai dimensi konsekuensi

e. Kinerja Pegawai

Kinerja Pegawai dalam penelitian ini ialah gambaran dari tingkat pencapainan pelaksaan suatu program pemerintah yang telah direncanakan/dicanangkan oleh pemerintah Provinsi Sumut dalam mewujudkan sasaran, tujuan, visi dan misi pemerintah Provinsi Sumut. Menurut Wilson Bangun menjelaskan cara untuk 


\section{Jurnal Ilmiah Ekonomi Islam, 7(02), 2021, 672}

mengukur kinerja pegawai adalah: (1) Jumlah pekerjaan, (2) Kualitas pekerjaan, (3) Kecepatan waktu, (4)Kehadiran, (5) Kemampuan kerja sama (Wilson Bangun, 2012).

\section{HASIL DAN PEMBAHASAN}

\subsection{Hasil penelitian}

Penelitian ini telah teruji valid dan reliabel. Dengan R hitung > R tabel yakni diatas 0,1818.

Tabel 1. Hasil Determinan (R2)

\begin{tabular}{|l|rr|r|}
\hline & & & \multicolumn{2}{|c}{ Model S } \\
Model & $\mathrm{R}$ & & R Square \\
1 & & $.659^{\mathrm{a}}$ & .434 \\
2 & & $.660^{\mathrm{b}}$ & .436 \\
3 & & $.685^{\mathrm{c}}$ & .469
\end{tabular}

Selanjutnya dengan signifikansi lebih kecil dari 0,05. Sehingga dianggap valid. Demikian dengan uji reliabilitas diaman cronbach Alpha diatas 0,60 sehingga setiap variabel penelitian dapat dikatakan reliabel.

Uji Koefisien Determinasi (R2)

Hasil analisis koefisien determinasi dalam penelitian ini dapat dilihat pada tabel 1 berikut:

a. Predictors: (Constant), MOTIVASI, PENDIDIKAN, PENGALAMAN

b. Predictors: (Constant), RELIGIUSITAS, PENDIDIKAN, PENGALAMAN, MOTIVASI

c. Predictors: (Constant), MOTIVASI*RELIGIUSITAS, PENDIDIKAN, PENGALAMAN, MOTIVASI, RELIGIUSITAS, PENDIDIKAN*RELIGIUSITAS, PENGALAMAN*RELIGIUSITAS

Sumber: hasil output SPSS diolah Februari 2021

Berdasarkan hasil output di atas diperoleh nilai $\mathrm{R}$ Square (R2) ialah:

\section{a. Model I}

Nilai R Square (R2) untuk model penelitian pertama adalah 0,434 atau $43,4 \%$. Hal ini menunjukkan bahwa persentase pengaruh variabel independen terhadap variabel dependen sebesar $43,4 \%$.

\section{b. Model II}

Nilai R Square (R2) untuk model penelitian kedua adalah 0,436 atau $43,6 \%$. Hal ini menunjukkan bahwa persentase pengaruh variabel independen variabel dependen serta variabel moderating sebesar $43,6 \%$.

c. Model III
Nilai R Square (R2) untuk model penelitian ketiga adalah 0,469 atau $46,9 \%$. Hal ini menunjukkan bahwa persentase pengaruh interaksi variabel independen dengan variabel moderating terhadap variabel dependen sebesar 46,9\%.

\section{Moderated Regression Analysis (MRA)}

Moderated Regression Analysis (MRA) atau uji interaksi merupakan aplikasi khusus regresi berganda linear yang didalamnya ada persamaan regresi dengan unsur interaksi (perkalian dua atau lebih variabel independen). Dalam penelitian ini yang menjadi variable dependen adalah Kinerja Pegawai (Y), variable independen adalah budaya pendidikan (1), pengalaman (X2) dan motivasi (X3). Selanjutnya Religiusitas (Z) sebagai variable pemoderasi.

Tabel 2. Hasil Uji Moderated Regression Analysis (MRA)

\begin{tabular}{|c|c|c|c|c|c|c|}
\hline & & \multicolumn{2}{|c|}{$\begin{array}{l}\text { Unstandardized } \\
\text { Coefficients }\end{array}$} & \multirow{2}{*}{$\begin{array}{l}\text { Standardized } \\
\text { Coefficients } \\
\text { Beta }\end{array}$} & \multirow[b]{2}{*}{$\mathrm{t}$} & \multirow[b]{2}{*}{ Sig. } \\
\hline \multicolumn{2}{|c|}{ Model } & B & Std. Error & & & \\
\hline \multirow[t]{4}{*}{1} & (Constant) & 7.753 & 2.491 & & 3.112 & .003 \\
\hline & PENDIDIKAN & -.239 & .134 & -.168 & -1.791 & .077 \\
\hline & PENGALAMAN & .526 & .120 & .445 & 4.390 & .000 \\
\hline & MOTIVASI & .404 & .100 & .385 & 4.023 & .000 \\
\hline \multirow[t]{5}{*}{2} & (Constant) & 7.422 & 2.608 & & 2.846 & .006 \\
\hline & PENDIDIKAN & -.241 & .134 & -.169 & -1.797 & .076 \\
\hline & PENGALAMAN & .526 & .121 & .445 & 4.363 & .000 \\
\hline & MOTIVASI & .367 & .129 & .350 & 2.835 & .006 \\
\hline & RELIGIUSITAS & .054 & .118 & .053 & .454 & .651 \\
\hline
\end{tabular}




\begin{tabular}{|c|c|c|c|c|c|c|}
\hline \multicolumn{7}{|c|}{ Jurnal Ilmiah Ekonomi Islam, 7(02), 2021, 673} \\
\hline & & \multicolumn{2}{|c|}{$\begin{array}{c}\text { Unstandardized } \\
\text { Coefficients }\end{array}$} & \multirow{2}{*}{$\begin{array}{c}\text { Standardized } \\
\text { Coefficients } \\
\text { Beta }\end{array}$} & \multirow[b]{2}{*}{$\mathrm{t}$} & \multirow[b]{2}{*}{ Sig. } \\
\hline \multicolumn{2}{|c|}{ Model } & $\mathrm{B}$ & Std. Error & & & \\
\hline \multirow[t]{8}{*}{1} & (Constant) & 18.979 & 27.839 & & .682 & .497 \\
\hline & PENDIDIKAN & .912 & 1.343 & .639 & .679 & .499 \\
\hline & PENGALAMAN & -2.224 & 1.297 & -1.880 & -1.714 & .091 \\
\hline & MOTIVASI & .985 & .914 & .939 & 1.078 & .284 \\
\hline & RELIGIUSITAS & -.503 & 1.309 & -.493 & -.384 & .702 \\
\hline & PENDIDIKAN*RELIGIUSITAS & -.050 & .060 & -1.244 & -.839 & .404 \\
\hline & PENGALAMAN*RELIGIUSITAS & .124 & .058 & 3.439 & 2.123 & .037 \\
\hline & MOTIVASI*RELIGIUSITAS & -.028 & .042 & -1.038 & -.656 & .514 \\
\hline \multicolumn{7}{|c|}{ a. Dependent Variable: KINERJA PEGAWAI } \\
\hline
\end{tabular}

Sumber: hasil output SPSS diolah Februari 2021

\section{a. Model I}

Persamaan regresinya sebagai berikut:

Kinerja Pegawai $=\alpha+\beta 1$ Pendidikan $+\beta 2$

Pengalaman $+\beta 3$ Motivasi $+\varepsilon$

Sehingga persamaan regresinya:

Kinerja Pegawai $=7,753+(-0,239)$ Pendidikan $+0,562$ pengalaman $+0,404$ motivasi $+2,491$

b. Model II

Persamaan regresinya sebagai berikut:

Kinerja Pegawai $=\alpha+\beta 1$ Pendidikan $+\beta 2$

Pengalaman $+\beta 3$ Motivasi $+\beta 4$ Religiusitas $+\varepsilon$

Sehingga persamaan regresinya:

Kinerja Pegawai $=7,422+(-0,241)$ pendidikan

$+0,526$ pengalaman $+0,367$ motivasi $+0,054$

Religiusitas $+\mathbf{2 , 6 0 8}$

c. Model III

Persamaan regresinya sebagai berikut:

Kinerja Pegawai $=\alpha+\beta 1$ Pendidikan $+\beta 2$

Pengalaman $+\beta 3$ Motivasi $+\beta 4$ Religiusitas +

$\beta 1$ Pendidikan $*$ Religiusitas $+\beta 2$

Pengalaman $*$ Religiustas $+\beta 3$

Motivasi*Religiustas $+\varepsilon$

Sehingga persamaan regresinya:

Kinerja Pegawai $=18,979+0,912$ pendidikan + $(-2,224)$ pengalaman $+0,985$ motivasi $+(-0,503)$ Religiusitas $+(-0,050)$ pendidikan*religiusitas + 0,124 pengalaman*religiustas $+\mathbf{0 , 0 2 6}$ motivasi*religiusitas $+27,839$

\section{Uji Parsial/Uji T}

Tabel di atas terdapat 3 model untuk dianalisis uji parsialnya, yaitu:

\section{a. Model I}

T tabel dalam penelitian ini adalah $\mathrm{Df}=\mathrm{n}-\mathrm{k} . \mathrm{Df}=83$ (sampel) 4 (variabel $)=79$. Maka $t$ tabel ialah 1,664. Jika $t$ hitung $>\mathrm{t}$ tabel dan nilai sig $<0,05$.
Hasil Uji parsial/Uji T model I penelitian ini ialah sebagai berikut: 1 . Pendidikan, nilai $\mathrm{t}$ hitung sebesar $-1,791$ dan nilai sig sebesar 0,077 . Untuk itu $-1,791<1,664$ dan $0,077>0,05$. Artinya pendidikan secara parsial tidak berpengaruh signifikan dan negatif terhadap kinerja pegawai di lingkungan Pemprov Sumut. 2. Pengalaman, nilai t hitung sebesar 4.390 dan nilai sig sebesar 0,000. Untuk itu 4,390 > 1,664 dan 0,000 <0,05. Artinya pengalaman secara parsial berpengaruh signifikan dan positif terhadap kinerja pegawai di lingkungan Pemprov Sumut. 3.Motivasi, nilai $t$ hitung sebesar 4.023 dan nilai sig sebesar 0,000. Untuk itu, 4,023>1,664 dan 0,000 < 0,05. Artinya motivasi secara parsial berpengaruh signifikan dan positif terhadap kinerja pegawai.

b. Model II

T tabel dalam penelitian ini adalah $\mathrm{Df}=\mathrm{n}-\mathrm{k} . \mathrm{Df}=83$ $($ sampel $)-5($ variabel $)=78$. Maka $t$ tabel ialah 1,664. Jika $t$ hitung $>\mathrm{t}$ tabel dan nilai sig $<0,05$. Hasil Uji parsial/Uji T model II penelitian ini ialah sebagai berikut: 1) Pendidikan, nilai t hitung sebesar -1.797 dan nilai sig sebesar 0,019. Untuk itu, $-1.797>1,664$ dan $0,076<0,05$. Artinya pendidikan secara parsial tidak berpengaruh signifikan dan negatif terhadap kinerja pegawai. 2) Pengalaman, nilai t hitung sebesar 4,363 dan nilai sig sebesar 0,000. Untuk itu, 4,363>1,664 dan $0,000<0,05$. Artinya pengalaman secara parsial berpengaruh signifikan dan positif terhadap kinerja pegawai. 3) Motivasi, nilai t hitung sebesar 2.835 dan nilai sig sebesar 0,006. Untuk itu, 2,835> 1,664 dan 0,006 < 0,05. Artinya motivasi secara parsial berpengaruh signifikan dan positif terhadap kinerja pegawai. 4) Religiusitas, nilai t hitung sebesar 0.454 dan nilai 


\section{Jurnal Ilmiah Ekonomi Islam, 7(02), 2021, 674}

sig sebesar 0.651 . Untuk itu $0.454<1.664$ dan $0.651<0,05$. Artinya religiusitas tidak berpengaruh secara parsial terhadap kinerja pegawai.

\section{c. Model III}

$\mathrm{T}$ tabel dalam penelitian ini adalah 1,665. Jika $\mathrm{t}$ hitung > t tabel dan nilai sig < 0,05. Hasil Uji parsial/Uji T model II penelitian ini ialah sebagai berikut: 1) Pendidikan, nilai t hitung sebesar 0.679 dan nilai sig sebesar 0.499. Untuk itu, $-0.679<$ 1.665 dan $0.499>0,05$. Artinya pendidikan secara parsial tidak berpengaruh signifikan dan positif terhadap kinerja pegawai. 2) Pengalaman, nilai t hitung sebesar -1.714 dan nilai sig sebesar 0.091. Untuk itu, $-1.714<1.665$ dan 0,091 >0,05. Artinya pengalaman secara parsial tidak berpengaruh signifikan dan negatif terhadap kinerja pegawai. 3) Motivasi, nilai t hitung sebesar 1.078 dan nilai sig sebesar 0,284. Untuk itu, $1.078<1.665$ dan $0.284>0,05$. Artinya motivasi secara parsial tidak berpengaruh signifikan dan positif terhadap kinerja pegawai. 4) Religiusitas, nilai t hitung sebesar -0.384 dan nilai sig sebesar 0.702. Untuk itu $-0.384<1.665$ dan $0.702>0,05$. Artinya religiusitas tidak berpengaruh secara parsial terhadap kinerja pegawai. 5) Pendidikan*Religiusitas, nilai t hitung sebesar 0.839 dan nilai sig sebesar 0.404. Untuk itu, -
$0.839<1.665$ dan $0.404>0,05$. Artinya pendidikan*Religiusitas secara parsial tidak berpengaruh signifikan dan negatif terhadap kinerja pegawai. Hal ini menyatakan religiusitas bukan variabel moderasi. 6) Pengalaman*religiusitas, nilai t hitung sebesar 0.656dan nilai sig sebesar 0.037. Untuk itu, $0.656>1.665$ dan $0,037<0,05$. Artinya pengalaman*Religiusitas secara parsial berpengaruh signifikan dan positif terhadap kinerja pegawai. Hal ini menyatakan religiusitas merupakan variabel moderasi. 7) Motivasi*Religiusitas, nilai t hitung sebesar 1.078 dan nilai sig sebesar 0.514. Untuk itu, $1.078<$ 1.665 dan $0.514>0,05$. Artinya motivasi*Religiusitas secara parsial tidak berpengaruh signifikan dan positif terhadap kinerja pegawai. Hal ini menyatakan religiusitas bukan variabel moderasi.

\section{Uji F (Simultan)}

Uji Simultan dengan F-test digunakan untuk mengetahui apakah pendidikan, pengalaman, dan motivasi secara simultan memiliki pengaruh yang positif atau negatif yang signifikan atau tidak terhadap kinerja pegawai. Pengujian yang dilakukan peneliti pada tingkat signifikansi 0,05 dan berdasarkan nilai $\mathrm{F}$ hitung.

Tabel 3. Hasil Uji F

\begin{tabular}{|c|c|c|c|c|c|c|}
\hline \multicolumn{7}{|c|}{ ANOVA $^{a}$} \\
\hline \multicolumn{2}{|c|}{ Model } & Sum of Squares & df & Mean Square & F & Sig. \\
\hline \multirow[t]{3}{*}{1} & Regression & 164.209 & 3 & 54.736 & 20.206 & $.000^{\mathrm{l}}$ \\
\hline & Residual & 214.008 & 79 & 2.709 & & \\
\hline & Total & 378.217 & 82 & & & \\
\hline \multirow[t]{3}{*}{2} & Regression & 164.772 & 4 & 41.193 & 15.053 & $.000^{7}$ \\
\hline & Residual & 213.445 & 78 & 2.736 & & \\
\hline & Total & 378.217 & 82 & & & \\
\hline \multirow[t]{3}{*}{3} & Regression & 177.481 & 7 & 25.354 & 9.473 & $.000^{1}$ \\
\hline & Residual & 200.736 & 75 & 2.676 & & \\
\hline & Total & 378.217 & 82 & & & \\
\hline \multicolumn{7}{|c|}{ a. Dependent Variable: KINERJA PEGAWAI } \\
\hline \multicolumn{7}{|c|}{ b. Predictors: (Constant), MOTIVASI, PENDIDIKAN, PENGALAMAN } \\
\hline \multicolumn{7}{|c|}{ c. Predictors: (Constant), RELIGIUSITAS, PENDIDIKAN, PENGALAMAN, MOTIVASI } \\
\hline \multicolumn{7}{|c|}{$\begin{array}{l}\text { DTIVASI*RELIGIU } \\
\text { DIKAN*RELIGIUS }\end{array}$} \\
\hline
\end{tabular}

Sumber: hasil output SPSS diolah Februari 2021 
Berdasarkan output di atas dapat dilihat bahwa nilai $\mathrm{F}$ hitung:

\section{a. Model I}

Nilai F hitung sebesar 26,398 dan tingkat probabilitas signifikan sebesar 0,000 . Nilai $f$ tabel untuk model I adalah sebesar DF1=3 (variabel bebas), $n=83$ maka $D f 2=83-3-1=79$. Maka $f$ tabel ialah 2,72 Sehingga diperoleh bahwa $F$ hitung $>F$ tabel yaitu 20,206 $>2,72$ dan 0,000 $<0,05$, maka dapat diambil kesimpulan bahwa pendidikan, pengalaman, dan motivasi secara simultan memiliki pengaruh yang signifikan dan positif terhadap kinerja pegawai di lingkungan Pemprov Sumut

\section{b. Model II}

Nilai F hitung sebesar 15.053 dan tingkat probabilitas signifikan sebesar 0,000 . Nilai f tabel untuk model II adalah sebesar DF1=4 (variabel bebas), $n=83$ maka Df2=83-4-1=78. Maka f tabel ialah 2,49 Sehingga diperoleh bahwa $F$ hitung $>F$ tabel yaitu $15.053>2.49$ dan $0,000<0,05$, maka dapat diambil kesimpulan bahwa pendidikan, pengalaman, motivasi dan religiusistas secara simultan memiliki pengaruh yang signifikan dan positif terhadap kinerja pegawai di lingkungan Pemprov Sumut.

\section{c. Model III}

F hitung sebesar 9.473 dan tingkat probabilitas signifikan sebesar 0,000 . Nilai $f$ tabel untuk model III adalah sebesar 2.13 Sehingga diperoleh bahwa F hitung > F tabel yaitu $9.473>2.13$ dan $0,000<$ 0,05, maka dapat diambil kesimpulan bahwa pendidikan, pengalaman, motivasi, religiusistas, pendidikan*religiusistas,

pengalaman*religiusitas, dan motivasi*religiusitas secara simultan memiliki pengaruh yang signifikan dan positif terhadap kinerja pegawai di lingkungan Pemprov Sumut.

\subsection{Pembahasan}

\section{a. Pengaruh Pendidikan Terhadap Kinerja Pegawai}

Hasil penelitian ini menunjukkan bahwa pendidikan tidak berpengaruh signifikan terhadap kinerja pegawai. Penelitian ini sejalan dengan penelitian yang dilakukan oleh Muhammad Teguh Nuryadin tahun 2019, I Kadek Yogi Setiawan tahun 2015, Serta penelitian Nova Wahyuni Syafnur pada 2019. Hasil temuan ini mendiskripsikan bahwa kinerja pegawai di lingkungan Pemprov Sumut tidak bergantung pada pendidikan yang ditempuh oleh pegawainya. Hal ini terjadi karena ketika bekerja, setiap pegawai harus dapat menjalankan tugas pokok yang diberikan atasan kepadanya. Meskipun tugas-tugas yang diberikan atasan tersebut tidak sesuai dengan latar belakang pendidikan pegawai tersebut. Adanya rotasi tugas yang dilakukan oleh atasan tanpa mempertimbangkan pendidikan dan jurusan pegawai juga menjadi penyebab tidak berpengaruhnya variabel pendidikan terhadap kinerja pegawai di lingkungan Pemprov Sumut. Hal ini dibuktikan dengan banyaknya pegawai yang kerap mengabaikan program-program pendidikan dan pelatihan salah satunya Diklat Pimpinan diberbagai unit kerja juga menjadi penyebab dari tidak berpengaruhnya variabel pendidikan ini. Padahal Diklat Pimpinan bertujuan untuk meningkatkan keilmuan, efektifitas kerja dan semangat kerja yang nantinya dapat meningkatkan kinerja Pegawai di Lingkungan Pemprov Sumut. Penelitian ini bertentangan dengan teori atribusi yang mana adanya pengaruh dari luar (eksternal) dalam hal ini pendidikan akan membentuk kepribadian seseorang.

b. Pengaruh Pengalaman Terhadap Kinerja Pegawai

Hasil penelitian ini menunjukkan bahwa pengalaman berpengaruh signifikan terhadap kinerja pegawai. Penelitian ini sejalan dengan penelitian yang dilakukan oleh Adriyan Muttaqin, Made Nurjida, Lulup Endah Tripalupi tahun 2013, I Kadek Yogi Setiawan tahun 2015. Hasil penelitian ini didukung oleh pendapat yang dikemukakan oleh Robbins dan Timothy bahwa "pengalaman kerja adalah tingkat penguasaan pengetahuan dan keterampilan seseorang dalam bekerja yang tampaknya menjadi sebuah dasar perkiraan yang baik atas kinerja karyawan" (Stephen P Robbins dan Timothy A. Judge, 2008). Pengalaman kerja memiliki peranan yang penting dalam melaksanakan pekerjaan. Karyawan yang lebih banyak memiliki pengalaman kerja akan lebih mengerti dan mampu dalam menyelesaikan pekerjaan, sebaliknya jika pengetahuan dan keterampilan karyawan tidak sesuai dengan pekerjaannya, maka kinerja karyawan akan rendah. Pegawai- 


\section{Jurnal Ilmiah Ekonomi Islam, 7(02), 2021, 676}

pegawai pemprovsu telah dapat berkembang dan beradaptasi di lingkungan kerjanya serta memiliki banyak pengalaman yang membantunya dalam menyelesaikan persoalanpersoalan yang terjadi dalam pekerjaannya. Banyaknya pegawai senior membantu pegawai junior untuk berkembang dan menyesuaikan diri dengan lingkungan yang ada. Dalam hal ini pegawai baru di lingkungan Pemprov Sumut dapat bertanya dan berdiskusi kepada rekan kerjanya yang lebih berpengalaman untuk mencapai tujuan dan menjalankan visi dan misi pemerintah dengan cepat dan tepat.

\section{c. Pengaruh Motivasi Terhadap Kinerja Pegawai}

Hasil penelitian ini menunjukkan bahwa motivasi berpengaruh signifikan terhadap kinerja pegawai. Penelitian ini sejalan dengan penelitian yang dilakukan oleh Rattu Andrey dkk pada tahun 2019 dan Desak Ketut Ratna Dewi tahun 2016. Teori atribusi menjelaskan kekuatan internal dapat membentuk perilaku seseorang. Kekuatan internal yaitu factor-faktor yang bersumber dari dalam diri seseorang yakni kepribadian, persepsi diri, kemampuan, religi/keyakinan dan motivasi. Konsep dasarnya yaitu seseorang yang mampu memahami tujuan yang diharapkan oleh organisasi, maka pemahaman tersebut akan mempengaruhi perilaku kerjanya. Pegawai di Lingkungan Pemprov Sumut secara keseluruhan, memiliki motivasi yang kuat dalam hubungannya untuk mencapai tujuan-tujuan yang ditetapkan dalam mewujudkan kinerjanya. Temuan dilapangan menemukan hasil bahwa Pegawai di Lingkungan Pemprov Sumut mempunyai keterampilan, mempunyai tujuan, dan menerima umpan balik untuk menilai kinerjanya. Hal ini sangat positif dalam menunjang kinerja dan mengevaluasi setiap pekerjaan dengan hasil yang di dapatkan. Dalam hal ini pula kebutuhankebutuhan pokok dan kesesuaian gaji, tunjangan dan kondisi kerja Pegawai di Lingkungan Pemprov Sumut sudah terpenuhi sehingga pegawai memiliki motivasi yang kuat dalam melaksakan aktivitas dan pekerjaannya seharihari.

d. Pengaruh Pendidikan, Pengalaman, dan Motivasi Terhadap Kinerja Pegawai

Hasil penelitian ini menunjukkan bahwa pendidikan, pengalaman, dan motivasi secara simultan berpengaruh signifikan terhadap kinerja pegawai. Penelitian ini sejalan dengan penelitian yang dilakukan oleh Rattu Andrey dkk tahun 2019, Damingun tahun 2018. Menurut Hasibuan, "kinerja merupakan perwujudan kerja yang dilakukan oleh karyawan yang biasanya dipakai sebagai dasar penilaian terhadap karyawan atau organisasi" (Hasibuan, Melayu, S. P, 2008). Kinerja yang baik merupakan langkah untuk tercapainya tujuan perusahaan. Oleh karena itu, setiap perusahaan perlu memiliki karyawan yang memiliki kinerja yang baik. Menurut Sutermeister dalam I Kadek Yogi Setiawan, kinerja dipengaruhi oleh "motivasi, kemampuan, pengetahuan, keahlian, pendidikan, pengalaman, pelatihan, minat, sikap kepribadian kondisikondisi fisik dan kebutuhan fisikologis, kebutuhan sosial dan kebutuhan egoistic. Sementara itu Teori Atribusi menjelaskan bahwa perilaku seseorang dipengaruhi oleh kekuatan eksternal dan internal yakni Kekuatan internal yaitu factor-faktor yang bersumber dari dalam diri seseorang (motivasi). Sementara itu, kekuatan eksternal yaitu factor-faktor yang bersumber dari luar diri seseorang (pendidikan dan pengalaman).

Dalam upaya meningkatkan kinerja, maka dibutuhkan karyawan yang memiliki pendidikan, pengalaman kerja dan motivasi yang kuat dalam meningkatkan kinerja karyawan. Sejatinya, pendidikan memiliki pengaruh terhadap kinerja karyawan, tinggi rendahnya tingkat pendidikan seseorang karyawan akan berpengaruh tehadap kinerja karyawan. Agar kinerja karyawan baik, maka diperlukan tenaga kerja yang memiliki tingkat pendidikan yang memadai yang sesuai dengan bidang pekerjaannya. Selain latar belakang pendidikan karyawan, kinerja karyawan dipengaruhi oleh masa kerja atau pengalaman kerja karyawan juga berpengaruh terhadap kinerja. Masa kerja atau pengalaman kerja juga dapat mempengaruhi kualitas kinerja karyawan. Kinerja karyawan yang belum memiliki masa kerja atau pengalaman akan berbeda dengan kinerja karyawan yang sudah memiliki masa kerja atau pengalaman kerja yang cukup banyak. Pengalaman kerja mencerminkan tingkat penguasaan pengetahuan dan keterampilan yang dimiliki seorang karyawan dalam bekerja yang dapat diukur dari masa kerja 
dan jenis pekerjaan yang pernah dikerjakan karyawan. Kombinasi ini akan menjadi sangat lengkap apabila dilengkapi oleh motivasi yang kuat dari pegawai. Pegawai yang memiliki motivasi yang kuat akan lebih bersemangat dalam menjalankan tugas-tugasnya sehingga pekerjaanya pun menjadi cepat dan lebih sempurna.

e. Pengaruh Pendidikan, Pengalaman, dan Motivasi Terhadap Kinerja Pegawai dengan Religiusitas sebagai variabel Moderasi

Hasil penelitian ini menunjukkan bahwa religiusitas memperkuat pengaruh Pendidikan, Pengalaman, dan Motivasi Terhadap Kinerja Pegawai. Berdasarkan uji regresi tunggal dan uji regresi berganda diperoleh perbandingan uji regresi tunggal < uji regresi berganda $(0,434<0,469)$. Sementara itu, religiusitas secara parsial diperoleh $0.454<1.664$ dan $0.651>0,05$. Artinya religiusitas tidak berpengaruh secara parsial terhadap kinerja pegawai. Penelitian ini sejalan dengan penelitian yang dilakukan oleh Dwi Rohayati dalam Hendy Prasetyo (Hendy Prasetyo dan Vera Anitra, 2020). Pemahaman keagamaan yang baik dan penerapannya dapat memunculkan kinerja yang baik pula. Seseorang yang selalu mengaplikasikan keimanannya dengan sepenuhnya pasti akan mempertimbangkan atas perilaku atau tindakan yang di lakukannya baik itu terkait secara hubungannnya dengan Allah (hablumminallah) maupun dengan manusia lainnya (hablumminannas). Dalam hubungannya dengan pekerjaan, manusia akan lebih cenderung untuk memperhatikan setiap langkahnya agar terhindar dari hal-hal yang diharamkan dan dilarang oleh agama. Factor religisuitas dalam penelitian ini tidak berdiri sendiri karena lingkungan kerja Pemprov Sumut merupakan lingkungan kerja yang umum (tidak Islami) dan terdiri dari berbagai agama. Namun demikian Pegawai di Lingkungan Pemprov Sumut kerap menjalankan norma-norma agamanya dalam menjalankan pekerjaannya. Adanya pendidikan yang baik diharapkan menambah pengetahuan agama setiap pegawai. Demikian dengan religiusitas sebagai pengalaman perasaan-perasaan atau pengalamanpengalaman keagamaan yang pernah dialami dan dirasakan selanjutnya religiusittas konsekuensi yakni sejauh mana perilaku seseorang dimotivasi oleh ajaran agamanya di dalam kehidupan sosial. Adanya motivasi yang kuat seperti apakah dia mengunjungi tetangganya yang sakit, menolong orang yang kesulitan, mendermakan harta dan sebagainya akan memperkuat ketaqwaan dan sikap religious pegawai di lingkungan Pemprov Sumut. Adanya penguatan ini tentunya berimplikasi pada peningkatan kinerja pegawai.

\section{KESIMPULAN}

Hasil yang diperoleh bahwa secara parsial pengalaman dan motivasi berpengaruh signifikan terhadap kinerja pegawai Pemerintah Provinsi Sumatera Utara. Namun secara parsial, pendidikan tidak berpengaruh signifikan terhadap kinerja pegawai pemerintah provinsi Sumatera Utara. Secara simultan pendidikan, pengalaman dan motivasi berpengaruh signifikan terhadap kinerja pegawai Pemerintah Provinsi Sumatera Utara. Sedangkan Religiusitas memperkuat pengaruh Pendidikan, Pengalaman, dan Motivasi terhadap Kinerja Karyawan. Diharapkan Pegawai di Lingkungan Pemprov Sumut mempertahankan kekuatan internalnya agar dapat berkembang lebih baik lagi dan teguh dalam penerapan norma-norma agama yang dianut agar pegawai dapat mencapai tingkat maslahah yakni kedamaian dunia dan akhirat. Diharapkan peneliti selanjutnya dapat mengkombinasikan variabelvariabel lainnya seperti variabel kompensasi, beban kerja dan lainnya dengan metode penelitian lain yang lebih kompleks.

\section{UCAPAN TERIMA KASIH}

Terimakasih kepada responden penelitian ini yakni pegawai Pemerintah Provinsi Sumatera Utara. semoga penelitian ini dapat bermanfaat bagi semua pembaca.

\section{REFERENSI}

Adofina, Wungow Raymond Octavianus, "Pengaruh Pengalaman Kerja dan Pelatihan Kerja Terhadap Kinerja Karyawan PT. Telkom Indonesia Cabang Manado," dalam Jurnal EMBA, Vol.6 No.3 Juli 2018, h. 1759.

Ali, Mohamad, Pendidikan Untuk Pembangunan Nasional, (Jakarta: Grasindo, 2009), h. 221-229) Andrey, Rattu, Pengaruh Pengalaman Kerja Dan Motivasi Terhadap Kinerja Karyawan Rumah Makan Di Manado, Jurnal EMBA vol.7 No. 1, Januari 2019, h. 361-370. 
Bangun, Wilson, Manajemen Sumber Daya Manusia (Jakarta: Erlangga, 2012), h. 235.

Biro Humas dan Keprotokolan SETDA Provinsi Sumatera Utara, Halalbihalal Pemprov Sumut, Gubernur Ajak ASN Tingkatkan Kinerja Dan Bekerja Dengan Hati, dalam https://humas.sumutprov.go.id, Dipublish Pada Oktober 2019.

Damanik, Carolin, Tak Puas, Gubernur Edy Rahmayadi Suruh PNS Kantongi Kertas Tupoksi Ke Mana-Mana, dalam https://medan.kompas.com dipublish pada November 2018.

Damingun, "Pengaruh Tingkat Pendidikan dan Masa Kerja Terhadap Kineja Pegawai Rektorat Universitas Universitas Mulawarman Samarinda," dalam Jurnal Ekonomi dan Manajemen Universitas Muhammadiyah Kalimantan Timur, Vol.12 No.1 Januari 2018, h. $1-18$

Dewi,Desak Ketut Ratna, dkk, Pengaruh tingkat Pendidikan dan Motivasi Kerja Terhadap Kinerja Karyawan, Jurnal Bisma Universitas Pendidikan Ganesha Vol. 4 Tahun 2016

Foster, Bill, Pembinaan Untuk Peningkatan Kinerja Karyawan (Jakarta: PPM, 2001), h. 43.

Hasibuan, Melayu, S. P, Manajemen Sumber Daya Manusia. Jakarta: Bumi Aksara, 2008)

I Wayan Suartana, Akuntansi Keprilakuan: Teori dan Implementasi, (Yogyakarta: Andi, 2010)

Leatemia, Senda Yunita. Pengaruh Pelatihan dan Pengalaman Kerja Terhadap Kinerja Pegawai pada Kantor Badan Pusat Statistik di Maluku, dalam Jurnal Manis Volume 2, No. 1, 2018.

Moeheriono, Pengukuran Kinerja Berbasis Kompetensi, Jakarta: PT grafindo Persada, 2012.
Mufidah, Zahrohtul, "Pengaruh Latar Belakang Pendidikan, Beban Kerja dan Lingkungan Kerja Non Fisik Terhadap Kinerja Karyawan PT. Bank BNI Syariah Cabang Kediri," dalam Jurnal Simki-Economic Vol. 01 No. 05 Tahun 2017. h. 1-16.

Ningsih, Ade Ratna, dkk, "Pengaruh Tingkat Religiusitas dan Kompensasi Dinansial Terhadap Etos Kerja Pegawai Pada Salon Muslimah House of Aisya Bogor," Al Amwal: Vol.1, 1 (Agustus 2018), 17.

Ningsih, Ade Ratna. dkk. Pengaruh Tingkat Religiusitas dan Kompensasi Dinansial Terhadap Etos Kerja Karyawan Pada Salon Muslimah House of Aisya Bogor, Al Amwal: Volume 1, No. 1, 2018

Poiyo, Yustin, et.all, “Pengaruh Gaya Kepemimpinan dan Disiplin Kerja Terhadap Kinerja Pegawai Pada Dinas Bali Pertanian

Rina Setiawati, Parmin, Pengaruh Religiusitas, Profesionalisme dan Human Capital Terhadap Kinerja Karyawan BMT Al Amin Gombong Dengan Motivasi Sebagai Variabel Intervening, dalam Jurnal Ilmiah Mahasiswa Manajemen, Bisnis dan Akuntansi, Vol. 1, No. 1, Oktober 2019, h.159.

Robbins, Stephen P. and Timothy A. Judge, Perilaku Organisasi, (Jakarta: Salemba Empat, 2014).

Setiawan, I Kadek Yogi, Pengaruh Latar Belakang Pendidikan Dan Pengalaman Kerja Terhadap Kinerja Pegawai Pada PT. Federal International Finance (Fif) Group Cabang Singaraja, (Jurnal Pendidikan Ekonomi (JJPE), Vol. 5 No. 1, 2015), h. 2

Yunita, Cut, et. all., Pengaruh Tingkat Pendidikan, Pelatihan, Masa Kerja dan Jabatan terhadap Pemahaman Laporan Keuangan Daerah Pada Pemerintah Aceh, JurnalAkuntansi Volume 1, No. 2, 2013. 